Arab Univ. J. Agric. Sci., Ain Shams Univ., Cairo, 13(2), 385-398, 2005

\title{
ENHANCING OF THE PERFORMANCE EFFICIENCY OF OILS BLEACHING EARTH
}

[24]

\author{
Girgis $^{1}$, A.Y.
}

\begin{abstract}
Various percentages of citric acid [0.05, 0.1, 0.15 and $0.2 \%$ ] were blended with the oil $(\mathrm{w} / \mathrm{v})$ before the bleaching of either soybean oil (SOO) or sunflower oil (SUO) to rise the performance efficiency of bleaching earth. Afterwards, activated bleaching earth was added to these oils for bleaching them at $1 \%$ level. Also, the same clay was used at $2 \%$ level for bleaching the above mentioned oils without using citric acid as a reference. The study revealed that better result for raising the bleaching efficiency of SOO was obtained with $0.15 \%$ citric acid. Whilst, $0.1 \%$ citric acid gave the best result pertaining the bleaching efficiency of SUO. Also, the data showed high reductions in the values of peroxide number, soap, conjugated dienes and trienes for the bleached oils with the increasing percent content of citric acid. While, the acidity values of the bleached oils (SOO and SUO) slightly increased with increasing citric acid percentages. On the other hand, using of citric acid at the ratios of 0.15 and $0.2 \%$ gave almost the same values in the bleaching efficiency of SOO. While, using of citric acid at the ratios of 0.1 and $0.15 \%$ gave nearly the same results of bleaching efficiency of SUO. Also, the data indicated that using of citric acid caused somewhat no changes in the fatty acid composition or their oxidative stabilities in the bleached oils. Therefore, it can be concluded that the reduction in the color of sunflower and / or soybean oils up to a levels of 33.3 and $36.7 \%$ is attainable by using either 0.1 or $0.15 \%$ citric acid prior to the bleaching step to decrease the imported content from bleaching earth to Egypt.
\end{abstract}

Key Words: Citric acid, Bleaching, Soybean and sunflower oils, Efficiency of bleaching earth.

\section{1- INTRODUCTION}

Bleaching clay is the natural adsorbent used for bleaching of edible oils (Brekke, 1990). Although degumming or refining will have removed phosphatides, free fatty acids and some impurities, soy- bean oil still contains color bodies and various impurities that need to be removed before the color and taste of the finished oil could be acceptable to the consumers. Some of these remaining impurities are further reduced in quantity by a process called bleaching which is used

1- Oils and Fats Research Department, Food Technology Research Institute, Agricultural Research Center, Giza, Egypt 
to improve the color and oxidative stability of oil (Erickson et al 1990 and DeGreyt \& Kellens, 2000). For many years, the bleaching process which consists of contacting the oil with an adsorbent materials, was considered purely from the standpoint of the removal of pigments (Mag, 1990 and Hamm \& Hamilton, 2000). Another function of bleaching is to remove decomposes peroxides and to adsorb the aldehydes and ketones resulting from decomposition of peroxides (Young, 1978 and Hui, 1996). Also, Park et al (2004) stated that activated bleaching earth has been used to adsorb the dark color matter. In addition to Gunstone et al (1994) suggested that the bleaching process induces reduction in oxidation levels by breakdown of the hydroperoxide primary oxidation product on the adsorbent surface, followed by adsorption of the carbonyl compounds. Also, they added that the degree of bleaching varies somewhat with the type of finished product. A highly bleached oil is used to prepare the typical whiteappearing shortening. More color a tinge of brilliant yellow is permissible for the oil used in margarine's, salad oil, salad dressings, and cooking oils (Goebel, 1976 and Brekke, 1990).

Citric acid can be used in refining process in various ways: to convert soaps to the more easily removed free acids and to act as a metal chelating agent (Law and Berger, 1984). Also, they added that citric acid is usually added to the oils in the form of $30-50 \%$ aqueous solution. On the other hand, Hamm and Hamilton (2000) indicated that citric acid decomposes rapidly above $150^{\circ} \mathrm{C}$. According to the results reported by Norris (1964); Goebel (1976) and Brekke (1990), the required dosage of bleaching earth used for the oils bleaching varies between 1.0 and $4.0 \%$.

Bleaching is by far the most expensive process in refining in terms of the operating costs of a bleaching plant due to the relatively high cost of the bleaching clays (Hamm and Hamilton, 2000). According to Chamber of Food Industry, Egyptian Industries Federation (The Egyptian Industry Ministry, 2003a), the production volume from oils and fats during 2002/2003 was about 750.000 tons. On the other hand, bleaching clays are imported to Egypt from some countries. In Egypt, the percentage of bleaching clay used for some oils bleaching usually ranges from 1 to $2 \%$ from the oil weight. Therefore, the imported content from bleaching earth to Egypt ranged from 7500 to 15000 tons during 2002/2003 for bleaching the whole 750000 tons. As for, the average price of imported activated bleaching earth is about 525 \$ USA per ton (The Egyptian Industry Ministry, 2003 b). While, the cost of adding citric acid in this work is very poor that ranges from 1 to $1.5 \$$ USA per ton. Hence, if citric acid can be used (as a solution) before the bleaching with $1 \%$ activated bleaching earth, it will reduce the imported content from activated bleaching earth to about the half (from 3750 to 7500 tons) and also, it will decrease the production cost of oils to about 1.96-3.92 million \$ USA per year.

The ultimate aim of this study was to rise the performance efficiency of activated bleaching earth by using citric acid before the bleaching of soybean and sunflower oils with $1 \%$ activated bleaching earth that will induce improvements in the color of both oils and the same time to decrease the imported content of activated bleaching earth to Egypt to about the 
half quantity, beside the production cost of these oils will be reduced.

\section{2- MATERIAL AND METHODS}

\subsection{Materials}

Refined soybean and sunflower oils were obtained from El-Ekhawa Company for Oils Processing, Saddat City, Menoufia Governorate, Egypt. While, activated bleaching earth (ABE) was brought from Cairo Oils and Soap Company, El-Aiat factory, Giza, Egypt which imported from Süd- Chemie Indonesia, Indonesia. Citric acid and all chemicals were purchased from El-Gomheria Company for Pharmaceutical, Cairo, Egypt.

\subsection{Bleaching treatments}

\subsubsection{Preparation of citric acid}

Concentrated solution of citric acid [CA] $(30 \% \mathrm{w} / \mathrm{v})$ in warmed propylene glycol $\left(50 \pm 2^{\circ} \mathrm{C}\right)$ was prepared and diluted directly by oils to the concentration percentages of $0.05,0.1,0.15$ and $0.2 \%$ $(\mathrm{w} / \mathrm{v})$ before the bleaching process.

\subsubsection{Procedure of the oils bleaching}

Refined soybean and sunflower oils were separately bleached under nitrogen laboratory according to the method described by Rolando (1991) with some modifications as follows: Various percentages of citric acid $(0.05,0.1,0.15$ and $0.2 \%$ of the oil weight $[\mathrm{w} / \mathrm{v}]$ ) (the concentration of citric acid solution was $30 \%$, w/v) were individually added to each oil $(500 \mathrm{~g})$ before the bleaching, then the oil was heated to $95 \pm 2{ }^{\circ} \mathrm{C}$ before adding $1 \%$ activated bleaching earth (ABE).
The mixture was then heated with stirring at $250 \mathrm{rpm}$ for $30 \mathrm{~min}$ with the maintenance of the same temperature $\left(95 \pm 2{ }^{\circ} \mathrm{C}\right)$ during the bleaching. Thereafter, the hot slurry (oil + clay) was cooled to $50 \pm 2^{\circ} \mathrm{C}$ and filtrated through filter paper (Whatman No.1) to separate the spent clay from the bleached oil. The bleached oils were analyzed, whereas, $2 \% \mathrm{ABE}$ was used for bleaching the same oils (soybean and sunflower oils) without using citric acid as a reference according to the above method.

\subsection{Methods of analysis}

\subsubsection{Determination of some physico- chemical analysis of activated bleaching earth}

$\mathrm{pH}$ value (10\% suspension) was measured using $\mathrm{pH}$ meter, Model HI9321, Hanaa, Instruments while, acid content was determined according to the methods reported by Anthony and Ogugua (1988). Whereas, moisture content was estimated by Electric oven at $105^{\circ} \mathrm{C}$ for $3 \mathrm{hr}$.

\subsubsection{Determination of some physical and chemical properties in soy- bean and sunflower oils}

Moisture and volatile matter (\%), acidity (\%) as oleic acid, peroxide number (meq. $\mathrm{O}_{2} / 1 \mathrm{~kg}$ oil) and soap content (ppm) in soybean and sunflower oils were determined according to the methods described in the A.O.C.S. (1997). While, the color values in both oils were measured by Lovibond Tintometer, Model E using 5.25 inch cell. Total color [Yellow $+10($ Red + Blue $)]$ and the percent color reduction were calculated using equation 
of Krishnan (1975), whereas conjugated dienes $\left(\mathrm{k}_{232} \mathrm{~nm}\right)$ and conjugated trienes $\left(\mathrm{k}_{270 \mathrm{~nm}}\right)$ of these oils were measured according to the methods reported in the IUPAC (1987) at 232 and $270 \mathrm{~nm}$, respectively, using U.V.-Vis. Spectrophotometer, Model Labmed, 120-02. As well as, refractive index of the above oils was measured by using Refractometer (NIRL3-Poland) according to A.O.C.S. (1997) method. While, the oxidative stabilities of the same oils were estimated according to the method described by Tsaknis et al (1999) using Metrohm Rancimat 679 at $100^{\circ} \mathrm{C}$ with air flow rate of $20 \mathrm{~L} / \mathrm{h}$.

\subsubsection{Methylation of soybean and sun- flower oils}

The methyl esters of soybean and sunflower oils were prepared (using benzene: methanol : concentrated sulfuric acid (10 $: 86: 4)$ and the methylation was performed at $90^{\circ} \mathrm{C}$ for one hour according to the method reported by Ludy et al (1968).

\subsubsection{Identification and determination of the fatty acid methyl esters in soybean and sunflower oils}

The fatty acid methyl esters of the above oils were separated and quantitatively determined using Gas-liquid chromatography (Pye-Unicam PRO- GC) according to Zygadlo et al (1994) method.

\section{3- RESULTS AND DISCUSSION}

Quality of the bleached oil is based upon free fatty acids content, Lovibond color and oxidative stability (Brekke, 1990 and Mag, 1990).

\subsection{Some physical and chemical prop- erties of the refined soybean and sunflower oils}

Some physical and chemical characteristic of the refined soybean oil (SOO) and sunflower oil (SUO) were determined and the results are represented in Table (I). From the data, it is appear that refined SOO and SUO had low content of moisture and volatile matter ( $\mathrm{m} \& \mathrm{vm})$. The maximal level of $m \& v m$ recommended by The Egyptian Standard Specifications (1993) is not excess than $0.1 \%$ for pure edible oils, whilst, the levels of acidity and peroxide number were inside the range reported by The Egyptian Standard Specifications (1993) for pure edible oils which limited that the levels of acidity and peroxide number must be not exceed than $0.2 \%$ and 10 meq. $\mathrm{O}_{2} / \mathrm{kg}$ oil, respectively. While, SOO had the highest total color (TC) than in SUO. This increment could be related to high content of red and blue units in SOO than in SUO. Soap content of the above mentioned oils was between 38 and 53 ppm, respectively.

The soap content normally accepted is $50 \mathrm{ppm}$ for pure edible oils (The Egyptian Standard Specifications, 1993). As to, the conjugated dienes and trienes in both oils (SUO and SOO) were in the range of 0.17 to 0.19 and 0.05 to 0.06 , respectively. Also, refractive index (RI) of the aforementioned oils was 1.4736 and 1.4728 , respectively. The above data for refined SOO and SUO are in conformance with Hamm and Hamilton (2000) but not agree with other researcher (Hui, 1996). These variations are nearly due to the difference in the processing procedure. 
Table I. Some physical and chemical properties of the refined soybean and sunflower oils.

\begin{tabular}{|c|c|c|c|c|c|c|c|c|c|c|c|}
\hline \multirow{2}{*}{ Oils } & \multirow{2}{*}{$\begin{array}{c}\text { Moisture } \\
\text { and } \\
\text { volatile } \\
\text { matter } \\
(\%)\end{array}$} & \multirow{2}{*}{$\begin{array}{l}\text { Acidity } \\
(\%) \text { as } \\
\text { oleic } \\
\text { acid }\end{array}$} & \multirow{2}{*}{$\begin{array}{c}\text { Peroxide } \\
\text { number } \\
\text { (meq. } \\
\mathrm{O}_{2} / \mathrm{Kg} \\
\text { oil) }\end{array}$} & \multicolumn{3}{|c|}{$\begin{array}{l}\text { Lovibond } \\
\text { color }\end{array}$} & \multirow{2}{*}{$\begin{array}{l}\text { Total } \\
\text { color }\end{array}$} & \multirow{2}{*}{$\begin{array}{l}\text { Soap } \\
\text { content } \\
(\mathrm{ppm})\end{array}$} & \multirow{2}{*}{$\begin{array}{c}\text { Conju- } \\
\text { gated } \\
\text { dienes } \\
(\text { at } 232 \\
\mathrm{nm})\end{array}$} & \multirow{2}{*}{$\begin{array}{c}\text { Conju- } \\
\text { gated } \\
\text { trienes } \\
(\text { at } 270 \\
\mathrm{nm})\end{array}$} & \multirow{2}{*}{$\begin{array}{c}\text { Refractive } \\
\text { index } \\
\text { (at } 25^{\circ} \mathrm{C} \text { ) }\end{array}$} \\
\hline & & & & Y & $\mathrm{R}$ & B & & & & & \\
\hline Soybean & 0.1 & 0.07 & 0.9 & 35 & 8.9 & 3.8 & 162 & 53 & 0.19 & 0.06 & 1.4728 \\
\hline $\begin{array}{c}\text { Sunflow- } \\
\text { er }\end{array}$ & 0.09 & 0.04 & 0.8 & 35 & 7.1 & 0.4 & 110 & 38 & 0.17 & 0.05 & 1.4736 \\
\hline
\end{tabular}

Where : $\mathrm{Y}=$ Yellow; $\mathrm{R}=$ Red; $\mathrm{B}=$ Blue.

\subsection{Some analyses of activated bleach- ing earth}

Activated bleaching earth (ABE) is one of adsorbent commonly used for oil bleaching (Brekke, 1990). The results in Table (II) are shown some analyses of ABE. From these data, it can be found that the moisture content of $\mathrm{ABE}$ was $12.1 \%$. This datum is within the range reported by DeGreyt and Kellens (2000) who stated that the water content in $\mathrm{ABE}$ usually varies between $10-20 \%$. On the other hand, Gunstone et al (1994) cited that $\mathrm{ABE}$ contains about $8-12 \%$ of free moisture. Also, the results indicated that $\mathrm{pH}$ value and acid content in $\mathrm{ABE}$ were 3.1 and $0.3 \%$, respectively. These data are somewhat close to that found by Hui (1996).

Table II. Some analyses of activated bleaching earth.

\begin{tabular}{|ccc|}
\hline $\begin{array}{c}\mathrm{pH}(10 \% \\
\text { suspension })\end{array}$ & $\begin{array}{c}\text { Moisture } \\
(\%)\end{array}$ & $\begin{array}{c}\text { Acid con- } \\
\text { tent }(\%)\end{array}$ \\
\hline 3.1 & 12.1 & 0.3 \\
\hline
\end{tabular}

\subsection{Effect of using citric acid on the fatty acid composition of the bleached soybean and sunflower oils}

The identifications of soybean and sunflower oils by Gas-liquid chromatography are given in Table (III). From the obtained results, it can be seen that these oils were rich in unsaturated fatty acids with linoleic acid being the major unsaturated fatty acid. Also, the findings showed that no obvious differences prevailing among the fatty acids of the bleached soybean oil samples (that treated and untreated with CA before the bleaching) were recorded. The contents of total saturated fatty acids (TSFA) in the bleached SOO were between 13.5 and $14.15 \%$, whilst the amount of total unsaturated fatty acids (TUFA) were in the range of 84.5 to $86.3 \%$. Also, the same trend was observed for the bleached sunflower oil. The amounts of TSFA in the bleached SUO were in the range of 9.7 to $11.62 \%$, while TUFA were between 88.2 and $89.0 \%$. These results indicated that using of CA at different ratios before the 
Arab Univ. J. Agric. Sci., 13(2), 2005 
bleaching caused slight changes in the fatty acids composition of soybean and sunflower oils. Accordingly, these findings of the fatty acids composition of both bleached SOO and SUO are within the range reported by Takagi \& Ando (1991); Gunstone \& Padley (1997); Hamm \& Hamilton (2000) and Judde et al (2003).

\subsection{Impact of using citric acid on some physical and chemical properties of the bleached soybean and sun- flower oils}

Effect of using various percentages of citric acid before the bleaching with either 1 or $2 \%$ activated bleaching earth $(\mathrm{ABE})$ on some physical and chemical characteristics of soybean oil (SOO) and sunflower oil (SUO) is shown in Table (IV). From these results, it is evident that there are interrelationship between citric acid content and soap level on the degree of the acidity in the bleached SOO and SUO which their acidities slightly increased with increasing of using citric acid content before the bleaching with $1 \% \mathrm{ABE}$ compared with that obtained in the oil that bleached with $1 \%$ ABE without using of CA before the bleaching (control) and simultaneously reduction in soap content was observed, which may be due to CA that induced breakdown in the ester bonds of the residual soap, so free fatty acids were released. These findings agree with those found by Law and Berger (1984) who stated that CA can be used in refining process to convert soaps to more easily removed free acids. According to Anonymous (1993), activated bleaching earth can lead to increase free fatty acids level during the bleaching. Also, the data tabulated in the same table reveal that addition of CA before the bleaching of the above mentioned oils occurred reductions in their values of peroxide number compared with that obtained in the control mentioned oil. On the other hand, the results reported by Aker (1990) and Hui (1996) indicated that the bleaching process induces reduction in oxidation levels by decomposition of hydroperoxide components.

The results of conjugated dienes and trienes are presented in Table (IV). These results indicate that using of $\mathrm{CA}$ before the bleaching of SOO and SUO with $1 \%$ $\mathrm{ABE}$ induced decrements in the values of conjugated dienes compared with that obtained in the control oil. These data are in accordance with those obtained by Brekke (1990) and DeGreyt and Kellens (2000) who pointed out that the bleaching step removes conjugated diene compounds, resulting from degradation of peroxide by dehydration. As to, refractive index of the above mentioned oils slight variations was recorded.

Also, the obtained results showed that the values of acidity, peroxide number, soap, conjugated dienes and refractive index in the same oils that bleached with $2 \%$ of the same bleached earth (ABE) without using citric acid were somewhat the same as those obtained in the same oils which treated with citric acid (at the ratios of 0.1 and $0.15 \%$ CA for SUO and SOO, respectively) before the bleaching with $1 \% \mathrm{ABE}$.

Therefore, using of citric acid before the bleaching of SOO and SUO with $1 \%$ $\mathrm{ABE}$ induced improvements in some physical and chemical properties of these oils and also reduced the used content from $\mathrm{ABE}$ to about the half quantity.

From the above results, it can be concluded that the best results for bleaching 
of SUO and SOO were obtained when using 0.1 and $0.15 \%$ citric acid, respectively before the bleaching with $1 \% \mathrm{ABE}$.

\subsection{Influence of using citric acid on the oxidative stability of bleached soy- bean and sunflower oils}

The oxidative stability of oils and fats is one of the most important factors determining their shelf life (Anwar et al 2003). The oxidative stability of SOO and SUO that treated with various percentage of $\mathrm{CA}$ before the bleaching with either $1 \%$ or $2 \%$ ABE was determined by programmed Metrohm Rancimat and the results are listed in Table (V). Rancimat is used to probe the oxidative stability in oils (Juarez et al 1998).

Table V. Effect of citric acid addition on the oxidative stability of bleached soybean and sunflower oils.

\begin{tabular}{|c|c|c|}
\hline \multicolumn{3}{|c|}{ Rancimat induction period (hr) } \\
\hline \multirow{2}{*}{$\begin{array}{l}\text { The used dosage } \\
\text { of citric acid } \\
(\%)\end{array}$} & $\begin{array}{c}\text { Soybean } \\
\text { oil }\end{array}$ & $\begin{array}{c}\text { Sunflower } \\
\text { oil }\end{array}$ \\
\hline & $\begin{array}{l}\text { After the bl } \\
\text { activated bl }\end{array}$ & $\begin{array}{l}\text { ing with } 2 \% \\
\text { ing earth }\end{array}$ \\
\hline \multirow[t]{2}{*}{ Non } & 8.48 & 6.41 \\
\hline & \multicolumn{2}{|c|}{$\begin{array}{l}\text { After the bleaching with } 1 \% \\
\text { activated bleaching earth }\end{array}$} \\
\hline Non & 8.25 & 6.0 \\
\hline 0.05 & 8.43 & 6.14 \\
\hline 0.1 & 8.55 & 6.25 \\
\hline 0.15 & 8.6 & 6.5 \\
\hline 0.2 & 8.71 & - \\
\hline
\end{tabular}

From the results, it can be indicated that slight increments were recorded in rancimat induction period (RIP) of both oils that treated with CA compared with that obtained in the control sample. Citric acid is sometimes used as chelating agent in the oils which help removing metal ions and oxygen scavengers and also it can regenerate spent antioxidant (Gunstone et al 1994 and Hui, 1996).

\subsection{Influence of using citric acid on the color of bleached soybean and sun- flower oils}

Effect of citric acid addition before the bleaching on the color of SOO and SUO is recorded in Table (VI). From these results, it is obviously that the color reduction percentage of $\mathrm{SOO}$ increased from $12.5 \%$ to $36.7 \%$ as content of citric acid increased from $0.05 \%$ to $0.15 \%$. This result is nearly due to the decrement in the values of Lovibond red and blue that decreased from 7.2 and 2.1 in the control sample to 4.2 and 0.4 in the same oil that treated with $0.15 \% \mathrm{CA}$, respectively. Also, the color reduction percentage in SUO increased from $12.1 \%$ to $33.3 \%$ as content of CA increased from $0.05 \%$ to $0.1 \%$. This improvement may be attributed to the reduction in the unites of Lovibond red and blue that reduced from 6.3 and 0.1 in the control sample to 3.1 and zero in the same oil that treated with $0.1 \% \mathrm{CA}$. These improvements in the color are probably inasmuch as using of CA which increased the bleaching efficiency of $\mathrm{ABE}$ by the reduction of some impurities (such as soap). Soap induces inhibition in the performance efficiency of bleaching earth (Hui, 1996). These results are in line with the limitation issued by The Egyptian Standard Specifications (1993) that stipulated that Lov- 
ibond red color of refined and bleached oil 
Arab Univ. J. Agric. Sci., 13(2), 2005 
should not be exceeded 7.0 units at yellow color of 35 . Also, the data in the same table show that the refined SOO treated with $0.15 \% \mathrm{CA}$ prior to the bleaching with $1 \%$ ABE was the best treatment of bleaching that recorded decrement in total color from 128 to 81, with highly bleaching efficiency (color reduction was $36.7 \%$ ). While the best treatment for bleaching of SUO was recorded at using of citric acid at the ratio of $0.1 \%$ which recorded reduction in total color from 99 to 66, with highly bleaching efficiency (color reduction was $33.3 \%$ ). On the other hand, the results indicated that using 0.15 and $0.2 \% \mathrm{CA}$ before the bleaching of SOO gave somewhat the same results since the bleaching efficiency of their color reductions recorded 36.7 and $38.3 \%$, respectively. Also, using 0.1 and $0.15 \% \mathrm{CA}$ before the bleaching of SUO gave somewhat the same results with respect to the bleaching efficiency since their color reductions were 33.3 and $35.3 \%$, respectively. From the above results, it is clear that using of CA up to $0.1 \%$ before the bleaching of SUO and up to $0.15 \%$ for SOO induced improvements in the color of these oils compared with that obtained in the control oil.

\section{4- CONCLUSIONS}

From all the above data in this work, it can be concluded that addition of citric acid to the refined sunflower and soybean oils up to 0.1 or $0.15 \%$ from the oil weight induced improvements in some parameters of these oils since the color became lightly, beside the values of soap, peroxide number, conjugated dienes, and trienes recorded reductions.
Subsequently, it can be recommended that citric acid can be added to the refined oils (sunflower and soybean oils) up to 0.10 or $0.15 \%$ from the oil weight (the concentration of citric acid was $30 \%$ ) before the bleaching with $1 \%$ activated bleaching earth to rise the performance efficiency of bleaching earth and to decline the imported content from activated bleaching earth to Egypt to about the half as well as to decrease the production cost of both oils (soybean and sunflower oils).

\section{REFERENCES}

Aker, A.R. (1990). Cottonseed: past, present, future. INFORM, 1(5): 565-567. Anonymous (1993). Die bleichung von speiseftten und-ölen. II. Fat Sci. Technol., 95:123-126.

Anthony, O. and C. Ogugua (1988). Laboratory trials on bleaching palm oil with selected acid-activated Nigerian clays. Food Chem., 27: 311-317.

Anwar, F.; M.I. Bhanger and T.G. Kazi (2003). Relationship between rancimat and active oxygen method values at varying temperatures for several oils and fats. J. Am. Oil Chem. Soc., 80(2):151-155.

A.O.C.S. (1997). Official and Tentative Methods for the American Oil Chemists Society $\boldsymbol{7}^{\text {th }} \boldsymbol{E d}$., Pub. by the Am. Oil Chem. Society, Champaign, U.S.A.

Brekke, O.L. (1990). Bleaching. In: Handbook of Soy Oil Processing and Utilization. pp.105 \& 107. Published by American Soybean Association and the American Oil Chemists' Society, U.S.A.

DeGreyt, W. and M. Kellens (2000). Refining practice. In: Edible Oil Processing. pp. 97\& 99. Hamm, W. and R.J. Hamilton, Ed. Sheffield, Academic Press, U.S.A., 
Erickson, D.R.; O.L. Pryde; T.L. Mounts and R.A. Falb (1990). HandBook of Soy Oil Processing and Utilization. pp.127, 128 \& 175. Published by American Soybean Association and the American Oil Chemists' Society, U.S.A. Goebel, E.H. (1976). Bleaching practices in the U.S. J. Am. Oil Chem. Soc., 53: 342-343.

Gunstone, F.D. and F.B. Padley (1997). Lipid Technologies and Applications. p. 41. Marcel Dekker, Inc., New York.

Gunstone, F.D.; J.L. Harwood and F.B. Padley (1994). The Lipid Handbook. pp. $267 \& 277$. Published by Chapman and Hall. London, Great Britain.

Hamm, W. and R.J. Hamilton (2000). Edible Oil Processing. pp. 8, 12, 25, 100, $101 \&$ 109, Sheffield Academic Press, U.S.A.

Hui, Y.H. (1996). Bailey's Industrial Oil and Fat Products. Vol. 2, pp. 26, 498, 522 \& 632. A Wiley Interscience Publication, John Wiley and Sons Inc., New York.

IUPAC (1987). Standard Methods for the Analysis of Oils, Fats and Derivatives. $7^{\text {th }}$ Ed. Palo Alto, California: Blackwell Scientific Publ., USA.

Juarez, L.A.; P.G. Diaz; N.G. Meza; J.O. Garcia; A.B. Moreno; L.B. Alvarado and O.A. Guerrero (1998). Effect of processing on the oxidative stability of soybean oil produced in Mexico. J. Am. Oil Chem. Soc., 75 (12): 1729-1733.

Judde, A.; P. Villeneuve; A. RossignolCastera and A. Le Guillou (2003). Antioxidant effect of soy lecithin on vegetable oil stability and their synergism with tocopherols. J. Am. Oil Chem. Soc., 80(12): 1209-1215.
Krishnan, S. (1975). Bernam bleachability test method for palm oil. $\boldsymbol{J}$. Am. Oil Chem. Soc., 52 (1): 23-27.

Law, K.S. and K.G. Berger (1984). Citric acid in the processing of oils and fats. Palm Oil Research Institute of Malaysia Technology, 11: 26-28.

Ludy, J.E.; R.A. Barford; S.F. Bard and D. Magidman (1968). A rapid and quantitative procedure for the preparation of methyl esters of butter oil and other fats. J. Am. Oil Chem. Soc., 45:549-552.

Mag, T.K. (1990). Edible fats and oils processing. World Conf. Proc., Maastricht, p. 107. American Oil Chemist's Society, Champaign.

Norris, F. (1964). Bleaching. In: Bailey's Industrial Oil and Fat Products, $3^{\text {rd }}$ Ed., pp. 769-792. Swern, D., Ed. Interscience Publishers, Division of John Wiley and Sons, New York.

Park, Y.E.; Ai Kato and H. Ming (2004). Utilization of waste activated bleaching earth containing palm oil in riboflavin production by Ashbya gossypii. J. Am. Oil Chem. Soc., 81 (1): 5762.

Rolando, C. (1991). Practical considerations in refining soybean oil. INFORM, 2 (3): 208-213.

Takagi, T. and Y. Ando (1991). Stereospecific analysis of triacylglycerols by chiral high-performance liquid chromatography. Lipids, 26:452-454.

The Egyptian Industry Ministry (2003a). The Annual Report of the Egyptian Industrials Federation, Cairo, Egypt.

The Egyptian Industry Ministry (2003 b). The Annual Report of the Holding Company for Industrials Food, Cairo, Egypt. 
The Egyptian Standard Specifications (1993). The Standard Specifications for Vegetable Edible Oil (No.44 / 1993). Egyptian Organization for Standardization and Quality Control, The Egyptian Industry Ministry, Cairo, Egypt. Tsaknis, J.; S. Lalas; V. Gergis; V. Dourtoglou and V. Spiliotis (1999). Characterization of mringa oleifera va- riety mbololo seed oil of Kenya. J. Agric. Food Chem., 47: 4495-4499.

Young, V. (1978). Chemical Introduction. pp. 692-703. Published by Chapman and Hall. London.

Zygadlo, J.A.; R.E. Morero; R.E. Abburra and C.A. Guzman (1994). Fatty acid composition in seeds oils of some onagraceae. J. Am. Oil Chem. Soc., 71(8): $915-916$. 
بحلة اتحاد الجامعات العربية للدراسات والبحوث الزراعية، جامعة عين شمس، القاهرة ، 13(2)، 385-398، 2005

\section{رفع كفاءة عمل تراب تبيض الزيوت}

[24]

\section{عادل يوسف جرجس 1 \\ 1- قسم بحوث الزيوت والاهون- معهد بحوث تكنولوجيا الأغذيةـ مركز البحوث الزراعيةـ الجيزة- مصر يور}

حموضـة تلك الزيـوت المبيضـة بزيـادة كمبـة حمض الستريك المستخدمة.

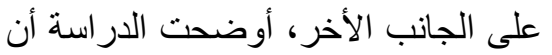
، إستخدام حمض الستريك بنسب 0.15 \% 0.2 أعطت إلى حد ما قيم منشابهة فى في كفاءة تبيض زيت فول الصويا. فى حين اشارت الدراسة أن استخدام نسب 0.1 و\%.15\% من حمض الستريك أعطت إلى في حد ما تنـابهه فى قيم كفاءة تبيض زيت عبن عباد الثمس. كذلك أوضحت النتائج أن استخدام

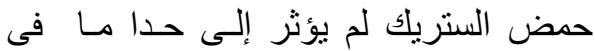

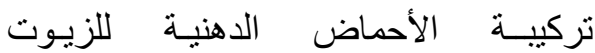

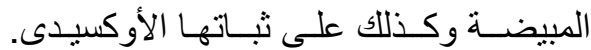

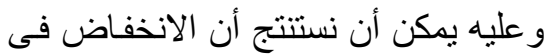

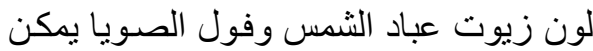
الوصــول إلبـهـ بمعـدل يصـل إلـــ 33.3 \%36.7 عند استخدام حمض الستريك بنسب

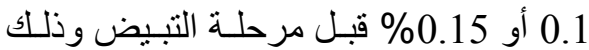
بغرض خفض كمية تراب التبيض المستوردة إلى مصر.
تم استخدام حمض الستريك بنسب مختلفة ( 0.05 ، 0.1 ، 0.15 ، 0.20 \% من وزن الزبت) قبل تبيض زيوت فول الصويا و عباد

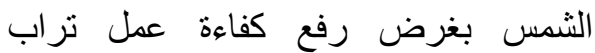
التبيض. اعقب ذلك تم إضافة 1\% نر بعرب تبيض نشط لتبيض تللك الزيوت. كذلك أُستخدم 2 \% من نفس تراب التبيض فى

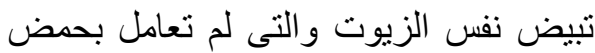
الستريك وذلك كمرجع.

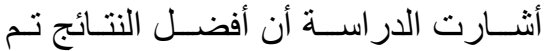

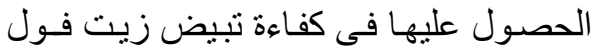
الصويـا عند استخدام حمض الستريـك بنسبة \% 0.15 فـى حبـن ســلت نسـبة 0.1 \%

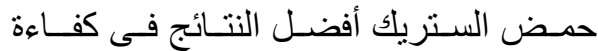
تبيض زيت عبـاد الثمس.

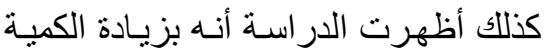
المسـتخدمة مسـن حمـض السـتريك يـز داد

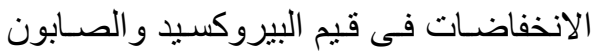
و المركبات التبادلية الثنائية و الثلاثية بـالزيوت المبيضة فى حين حدث زيـادة بسيطة في قيم

تحكيم: ا.د ممدوح حلمى القليوبى ا.د شاكر رزق شحاتـه 